\title{
4. Canada: the politics of optimism
}

\author{
Anastasia Glushko
}

\section{Warranted optimism or an illusion of invulnerability?}

In late 2008, billionaire investor Warren Buffet called the financial crisis a 'financial Pearl Harbor' (Clark 2008) and former US Federal Reserve Chairman Alan Greenspan described it as a 'once-in-a-century event' (Stein 2008). Like the problem itself, however, Canada's experience of, and its government's response to, the financial meltdown have been more ambiguous. Canada entered the economic turbulence from a position of relative strength and suffered far less than would be expected of a country whose economy was so dependent on its southern neighbour. At the time of writing, Canada's financial system has been less affected by the global financial crisis than those of other industrialised countries such as the United States and the United Kingdom, and its banks have not required an injection of government capital. In fact, in October 2008, the World Economic Forum ranked Canada first in the world for the soundness of its banking system and, in March 2009, Canada's banks were expected to report another profitable quarter, defying global trends (Hopkins 2009).

On the other hand, no one major country in the world is as dependent on another nation for its economic wellbeing as Canada is on the United States. Canada ships almost four-fifths of its exports to the United States (Statistics Canada 2008), and all of Canada's recent surpluses in its current account are attributable to the United States' buying power (Fry 2009:35-6). In addition, investors in the United States account for about 58 per cent of the foreign direct investment stock in Canada and these investments have provided more than one million jobs for Canadian workers. Canada's tourism and hospitality sectors have also been seriously dependent on the United States since Americans account for about 80 per cent of all foreign visitors to Canada (Fry 2009:35-6).

As a result, the effects of the global financial crisis on the Canadian economy did not begin to be felt until late in 2008 and early 2009, when the reduction in American consumption began to translate into difficulties for Canada's export, service, auto and primary sectors. Rising unemployment, reduction in foreign investment and the falling value of the local currency were particularly significant manifestations of the financial crisis in Canada. Indeed, the full extent of its impact was being fully understood - and suffered - by ordinary Canadians only as of early 2009. 
The three people responsible for leading Canada through this crisis and therefore subject to analysis in this study are Prime Minister Stephen Harper, Minister for Finance Jim Flaherty, and the Governor of the Bank of Canada Mark Carney. Harper and Flaherty are members of the Conservative Party, which has been a minority government since 2006. Carney's post is not political, since the Bank of Canada's Board of Directors appoints the governor. As this study will show, however, it was precisely the apolitical nature of his office that conferred significant importance and legitimacy on his public pronouncements - and meant Carney was a significant figure in shaping public opinion about the events.

Because the real extent of the effects of the crisis on the Canadian economy was not revealed until the end of 2008, for most of that year, the Conservative Government was able to exploit its position of incumbency and Harper's reputation as a respected economist - specifically, that Harper, who held an MA in economics, was Canada's first Prime Minister to be a professional economist. Emboldened by an economy that seemed largely unaffected by the crisis that was engulfing the rest of the world, and by a weak and divided opposition, the usually cautious Harper called an early election in October 2008. He asked Canadians for a mandate to lead the country through the financial storm (though it was widely accepted that he was also hoping to secure a parliamentary majority the Conservatives had hitherto lacked). Although the Harper Government was comfortably returned (albeit without a majority), the September election campaign, coupled with the simultaneous rapid fall on Wall Street, facilitated public discussion and awareness of the severity of the meltdown and revealed considerable flaws in the Conservatives' public framing of the crisis. After the election, the government's optimistic outlook proved to be increasingly fragile, as the reverberations of the global crisis steadily permeated the Canadian economy. The government was forced to rescind on its assurances that Canada's economy was so sound that it would even produce a surplus in the subsequent fiscal year. In fact, the government had to concede that Canada's economy was officially in recession and that the country would be forced to produce a deficit, the projected amount of which inflated from $\$ 30$ billion in January 2009 to $\$ 50$ billion at the time of writing in June (Jones 2009).

The continuous policy backtracking since December 2008 saw the government's credibility erode significantly. Its apparent reluctance to admit the severity of the crisis created a perception that the Conservative Government lacked empathy for ordinary Canadians hit by the crisis. Despite these setbacks, the government remained in a position of relative strength in June 2009. It was enabled by politically weak opposition parties, who had been riddled with their own leadership difficulties and who, despite the opportunity the crisis presented, were unable to put aside their divisions to effectively challenge the government on the basis of economic competency. A telling example was the parliamentary crisis in December 2008 when the Harper Government found itself facing the 
prospect of defeat in the House of Commons on a motion of confidence brought by the three opposition parties. In addition, the three parties signed a formal coalition agreement providing for a Liberal-NDP coalition government (supported by Bloc Quebecois) to assume power if the government was defeated. The government was forced to prorogue Parliament for two months, but the coalition fell apart almost as soon as Parliament returned, unable to agree on an appropriate response to the budget, thus ending the parliamentary crisis.

\section{Box 4.1 Canada's financial crisis trajectory, April 2008 - April 2009}

24 April 2008: Finance Minister, Jim Flaherty, announces that the government will tighten securities regulation to force more disclosure by financial institutions about their investments.

2I August: According to Statistics Canada, 15 of 22 industry groups reported higher profits, led by oil and gas extraction and manufacturing. Canadian corporations earned $\$ 69.4$ billion in operating profits in the second quarter - up 2.5 per cent from the first quarter.

22 August: Flaherty uses his department's monthly fiscal update to announce that the Federal Government has revised its working estimate for growth to 1.1 per cent from the 1.7 per cent forecast in the February budget.

28 August: The Harris/Decima Investors Group Survey indicates that pessimism about the economy in the coming year fell 6 per cent since the previous survey in May, to 32 per cent.

6 September: Findings show Canadian employers hired 161,000 people in August, maintaining the unemployment rate at 6.1 per cent.

7 September: Prime Minister Stephen Harper, calls an early election for 14 October.

II September: Labour productivity falls for the third consecutive quarter, highlighting a marked deterioration in Canada's competitiveness and a signal that growth is slowing.

I5 September: As the Toronto Stock Exchange (TSX) closes down 515.55 points, Harper warns against economic pessimism about the unfolding US financial crisis, saying that if an economic crash was coming, it would have happened already.

I9 September: Harper says Canadian financial institutions have not been hit hard by the US financial crisis; therefore, there is no need for a bailout of Canada's chartered banks. 
23 September: Statistics Canada says Canada's consumer price index is at its highest point since March 2003 due to thriving food and gas inflation.

24 September: The Bank of Canada pledges $\$ 4$ billion to unfreeze credit markets; Statistics Canada says inflation jumped to 3.5 per cent in August - the highest rate since early 2003.

25 September: The Bank of Canada pledges a further $\$ 6$ billion in emergency short-term lending to help lenders deal with tighter credit markets.

29 September: The TSX closes 841 points down - the biggest one-day point drop ever - as the US Congress votes down the bailout package; Scotiabank Commodity Index drops 8.9 per cent.

30 September: The Bank of Canada injects an additional \$4 billion into short-term money markets as a means to increase the flow of credit.

I October: Volvo closes its Ontario plant, with a loss of 500 jobs; Statistics Canada says Canada's economy boomed in July, growing 0.7 per cent on the strength of surging energy output - the fastest pace of growth since March 2004.

8 October: Central banks announce coordinated rate reductions and the Bank of Canada lowers its interest rate by 0.5 of a percentage point to 2.5 per cent.

Io October: The Canadian dollar experiences its biggest one-day drop since 1971 .

I4 October: Harper's government is re-elected.

I9 October: Flaherty predicts a 'modest' surplus for the current fiscal year.

2I October: The Bank of Canada lowers its interest rate by 0.25 of a percentage point to 2.25 per cent.

24 October: The government guarantees bank loans.

30 October: Harper announces a new cabinet, enlarging it to 38 members and increasing Ontario's representation. Three of the most heavyweight portfolios (finance, industry and transport) remain unchanged; the opposition criticises the retention of Flaherty.

3I October: The Harper Government announces it will limit the growth of equalisation payments to poorer provinces in light of the global financial crisis. 
I November: Bank of Montreal and Bank of Nova Scotia say Canada is entering a recession; the government denies it.

Io November: General Motors' shares drop to a 60-year low. The auto industry is Canada's largest industrial sector by employment, accounting for 12 per cent of manufacturing gross domestic product (GDP) and employing more than 500,000 Canadians.

12 November: Canadian stocks fall below 9000 points, as investors ignore a new Canadian Government pledge to better stimulate lending by the banks.

20 November: Harper makes his reply to the 'Speech from the Throne', emphasising that he will act quickly to protect Canadians in a time of global instability.

24 November: Flaherty concedes that Canada is in recession; the Canadian dollar is up 3.5 per cent, buoyed by the bailout of Citigroup.

3o November: Flaherty announces a five-year economic action plan to stimulate the economy.

9 December: The Bank of Canada lowers its interest rate by 0.75 of a percentage point to 1.5 per cent.

20 January 2009: The Bank of Canada lowers its interest rate by 0.5 of a percentage point to 1 per cent.

24 February: Parliament passes the Economic Action Plan, which seeks to provide almost $\$ 64$ billion over two years to support the Canadian economy, including money for infrastructure, tax cuts and changes to the employment insurance scheme. The government predicts a deficit of $\$ 34$ billion in the next financial year, and $\$ 30$ billion in the year after that.

2 March: The Canadian dollar hits a three-month low against the US dollar, exacerbated by renewed risk aversion and the declining price of crude oil. A Statistics Canada report reveals that Canada's GDP shrank by 3.4 per cent in the fourth quarter - one of the lightest declines among the major global economies. On an annual basis, GDP fell by 0.7 per cent - the first decline in the annual rate since 1991.

3 March: The Bank of Canada lowers its rate by 0.5 per cent to 0.5 per cent.

II March: The International Monetary Fund (IMF) announces that Canada is 'better placed than most' to weather the global recession due to a strong fiscal package announced in January and a healthy financial sector. 
6 April: A study by the Canadian Centre for Policy Alternatives finds that rapid contractions of the economy and the job market eclipsed the Harper Government's stimulus package before any money was even dispensed. The study reports that the package laid out in the 27 January budget was too small, too late and 'out of proportion to the threat that Canadians are currently facing'.

9 April: The Statistics Canada Labour Force Survey shows employment declined by 61,000 places in March 2009, pushing the unemployment rate up 0.3 of a percentage point to 8 per cent - the highest rate in seven years.

\section{Methodological considerations}

This chapter follows the overall research design of this volume, so no detailed account of key concepts, propositions and study design principles is provided here. A few observations are in order, however, on the specifics of the speeches and newspapers selected for further analysis. The selection of key speeches was determined by the amount of media coverage they received. This was because the initial process of compiling a timeline of the crisis in Canada revealed a notable lack of general media interest (as manifest in the lack of coverage) in the manner in which the Canadian Government was handling the crisis, despite its magnitude. In addition, particular events that received considerable international coverage and could reasonably be assumed to have been of significance to Canadians - such as the biggest one-day drop in the Canadian dollar's value, the government's guarantee of banks loans and the proroguing of Parliament - curiously did not attract very much coverage. This indicated that to determine which events and consequently which particular speech acts registered on the Canadian public's radar (and therefore presented opportunities to frame the crisis), a comprehensive search of the chosen media outlets was necessary.

Thus, every article containing a reference to the economic crisis in chosen publications within the specified time frame was examined in chronological order. Speech acts that related to events that received significant media attention generally received significant coverage themselves and were selected for this merit. A secondary search of references to the selected speech acts and events was also conducted to ensure no coverage was missed. This method, although painstaking and time consuming, meant that the process of selection of relevant newspaper articles was almost simultaneous with the selection of the speeches.

The newspapers chosen for analysis in this study were The Globe and Mail and the National Post, as well as its business section, the Financial Post - two national 
newspapers with high circulation. It is worth noting that the Toronto Star has the highest circulation of all newspapers in Canada and was initially considered. A closer examination, however, revealed that the Toronto Star could be classified more accurately as a provincial newspaper, due to its preoccupation with Ontario-based issues. The high levels of circulation can likely be attributed to the fact that Ontario is by far the most populated province, with almost 13 million residents, compared with the 4.5 million in British Columbia, for example (Canadian Newspaper Association 2008:4-5).

The choice of national newspapers is admittedly limiting. Both newspapers are fairly conservative in their journalistic ethos and mostly endeavour to avoid particular bias (or attempts to influence public opinion) compared with some of their more colourful provincial counterparts. Moreover, given the strength of historical and economic divides between the provinces, regional (mostly tabloid) newspapers such as the Vancouver Sun, The Calgary Herald or Le Devoir are often read more widely in their respective localities than are the national broadsheet papers (Canadian Newspaper Association 2008:6-9). The crisis, however, affected different Canadian provinces in different ways; central Canada was by far the worst hit because of its reliance on service and auto manufacturing industries and the crisis was most painfully manifested in high levels of unemployment. On the other hand, the wealthier oil and gas-producing provinces of British Columbia and Alberta were far less affected, and the main issues for people there were fluctuating commodity prices that generated high levels of anxiety but, by early 2009, no significant job losses.

Provincial newspapers reveal a perennial preoccupation with their provincial interests rather than national issues, which presents a significant obstacle when attempting to measure popular and media opinion in Canada. With this in mind, the study does on occasion consider a small cross-section of provincial coverage, particularly where there were wide discrepancies between the views conveyed in national and provincial papers.

The selected articles were summarised and then coded using a three-point scale of agreement (agreement, disagreement or neutral/no comment) against four analytical categories, which referred to the leaders' framing of the severity and the causality of the crisis, proposed policy implications and overall support for the leader. This method was useful in demonstrating the amount of coverage each speech act received and provided a useful basis when analysing media interest (or lack thereof) in the government's framing of the crisis. These findings were, where possible, supplemented with relevant national public opinion polling statistics, reflecting the government's popularity and credibility. The findings were interpreted through the lens of the crisis exploitation framework described in Chapter 2. 


\section{Crisis development and elite rhetoric in Canada}

\section{May 2008: the Finance Minister's assertion of Canadian resilience}

Jim Flaherty used his address to the Economic Club of Toronto to assure Canadian voters that Canada's economy would prove to be resilient. He acknowledged a number of challenges facing the Canadian economy: the US housing market, volatile financial markets, the strong Canadian dollar (in the face of waning demand for exports), energy prices and an ageing population. He used upbeat rhetoric, however, to argue that Canadian banks were well capitalised, the local housing market was solid and more Canadians were working than before. He also made a number of historical references to Sir John A. Macdonald, the first Prime Minister of Canada, whose tenure spanned 18 years and who was the only Canadian prime minister to win eight majority governments. He drew parallels between Macdonald's preference to 'always look a little ahead' and his own government's preference for grounding broader economic policies in the long term, rather than 'band-aid, ad hoc solutions'.

Given the extent to which Canadians were exposed to the US media (and what would have already been a daily drumbeat of dire economic news), this speech served a vital function in shaping Canadian public opinion of the domestic manifestations of the global financial crisis and its causes. This was particularly significant given the incumbency of the Harper Government - and therefore its vulnerability to blame for the impact of the crisis on Canada.

\begin{tabular}{|l|l|l|l|l|}
\hline & Severity & Causality & $\begin{array}{l}\text { Policy } \\
\text { implications }\end{array}$ & $\begin{array}{l}\text { Support for } \\
\text { speaker }\end{array}$ \\
\hline Agrees & 1 & & 1 & 1 \\
\hline Disagrees & & & & \\
\hline $\begin{array}{l}\text { No comment/ } \\
\text { neutral }\end{array}$ & 1 & 2 & 1 & 1 \\
\hline
\end{tabular}

\section{Table 4.1 Media response to Flaherty's 12 May 2008 speech}

The global financial crisis did not start to affect Canada seriously until about October 2008 and the Canadian public did not fully accept the fact even a number of months after that. At this stage of the crisis, media agreement with proposed policy implications was closely tied to support for the national leaders, since the Canadian Government had not proposed any new measures to deal with the crisis, instead emphasising the importance of 'staying the course'. While a lack of media interest in Flaherty's subsequent public pronouncements might have indicated a level of public despondency with the Harper Government, the fact that this speech attracted very minimal coverage in May 2008 was a big positive for the Conservative Government. A Strategic Counsel opinion poll conducted 
shortly after Flaherty's speech showed that the Conservatives enjoyed the support of 38 per cent of decided voters - down only 1 per cent from a high of 39 per cent in February 2006 (Strategic Counsel, CTV and Globe and Mail 2008a) and, a month later, the same poll showed that 38 per cent of people felt the Conservative Party was best able to manage the economy in the case of a downturn-compared with the Liberal Party's 27 per cent (Strategic Counsel, CTV and Globe and Mail 2008b). It can therefore be concluded that the reason why Flaherty's 12 May speech received little public attention was because the global economic crisis was not yet a major issue for the Canadian media and public. Flaherty's choice of using consistently positive rhetoric and downplaying the interdependence of the US and Canadian economies, however, proved an effective meaning-making strategy for the time being.

\section{September 2008: bank governor Carney's crisis narrative}

Mark Carney used his address to the Canadian Club of Montreal to outline how the upheaval in global financial markets and the slowdown in the US economy were important international factors affecting the Canadian economy. Using blunter language than Canadians had come to expect from their government, Carney said that global markets were now at a critical juncture and the nature of the slowdown in the US economy - with weakness in the housing and auto sectors-posed particular problems for Canadian exports. He also argued, however, that the turmoil might be cathartic in restructuring markets, prompting decisive policy responses and speeding up the reordering of the financial system to make the world more stable. He concluded that Canada's financial system was well positioned to weather the financial storm because it had been prudent and soundly capitalised. He added that the Bank of Canada would continue to monitor economic and financial developments carefully and would 'continue to set monetary policy consistent with achieving the two per cent inflation target over the medium term'.

From the outset, it is worth noting that beyond announcements affecting interest rates, public pronouncements from the Bank of Canada have rarely attracted much media attention. This could probably be attributed to the level of detail provided by Carney and the Bank of Canada, which was uninteresting or difficult for ordinary Canadians to understand (Financial Consumer Agency of Canada 2008). It was also for this reason that the media often oversimplified Carney's speech acts. Of the five articles analysed, four essentially disagreed with Carney's positive assessment of Canada's economy and portrayed the severity of the economic crisis as very acute (Table 4.2). All five left out Carney's assurances that Canada's financial system was well placed and that high commodity prices could even benefit the Canadian economy, and they expressed very pessimistic observations about the prospects for the Canadian economy. 


\begin{tabular}{|l|l|l|l|l|}
\hline & Severity & Causality & $\begin{array}{l}\text { Policy } \\
\text { implications }\end{array}$ & $\begin{array}{l}\text { Support for } \\
\text { speaker }\end{array}$ \\
\hline Agrees & & 5 & & 2 \\
\hline Disagrees & 4 & & 1 & \\
\hline $\begin{array}{l}\text { No comment// } \\
\text { neutral }\end{array}$ & 1 & & 4 & 3 \\
\hline
\end{tabular}

Table 4.2 Media responses to Carney's 25 September 2008 speech

Unlike Harper and Flaherty, who preferred to avoid any discussion of causality in their public pronouncements, Carney appeared to view explaining what had happened as part of his job as the Governor of the Bank of Canada. All five articles agreed with Carney's assessment of the causes of the crisis. Perhaps because Canadians realised that Carney had nothing to gain politically by exploiting the crisis, and perhaps because they did not realise that it was in his professional interest to keep public confidence buoyant, none of the articles expressed criticism of him. In covering this speech, however, three articles showed disapproval of the Harper Government and portrayed Flaherty and Harper as dishonest, clueless and uninformed.

It is also worth noting that Carney's speech attracted significant attention in media sources not used in this study, particularly regional newspapers. Local media sources such as the Prince George Citizen and The Montreal Gazette produced very positive accounts of his pronouncements and focused on his assertion that Canada could weather the US storm. In the midst of all the gloom coming from national and US media sources, regional Canadians clearly craved some positive news.

\section{October 2008: Prime Minister Harper's bid for re-election}

This speech, the release of his party's election platform, marked a deliberate attempt by Harper to reverse the downward trend in support for the Conservative Party. Hitherto in the election campaign, Harper had taken advantage of his position as the frontrunner and as leader of the incumbent party. He had refrained from presenting a comprehensive package. Although acknowledging that 'Canada is heading into a period of economic uncertainty and slower growth', Harper used this speech to urge Canadians not to panic because Canada was well placed to weather the financial storm. Responding to criticisms that the government had not responded quickly enough to the global financial crisis, Harper said his opponents were panicking and he vowed to stay the course: 'prudent leadership does not set out economic strategy for the nightly news or re-write plans for the morning papers...you don't shift long term plans for short-term considerations.' The speech emphasised previous achievements: variations on the phrase 'we will continue to' and 'the Conservative government has already' recurred in the 
text. In contrast with Harper's usually very reserved and formal communication style, this speech made a memorable pseudo-biblical reference ('the plan on which we have been acting is the plan...as the saying goes, it wasn't raining when Noah built the Ark'), which was ridiculed by some commentators.

The policy proposals were modest, probably in order to complement the government's mantra that Canada's banks were insulated from the building storm in global markets. This logic had seemed like a winning one in early September when the Conservative Party called the snap election hoping to secure the majority 'before the tidal wave sweeping the global financial system breached Canada's levies' (Callan 2008). As the global financial crisis deepened, however - the Toronto Stock Exchange dropped 3942 points or 28.6 per cent between 1 September and 8 October (The Economist 2008) - and media discussion and awareness about its causality and severity increased, this 'happy-go-lucky' message (The Globe and Mail 2008) proved to be fragile and increasingly irrelevant as it was largely abandoned by many of Canada's top banks.

\begin{tabular}{|l|l|l|l|l|}
\hline & Severity & Causality & $\begin{array}{l}\text { Policy } \\
\text { implications }\end{array}$ & $\begin{array}{l}\text { Support for } \\
\text { the speaker }\end{array}$ \\
\hline Agrees & 2 & 4 & 3 & 1 \\
\hline Disagrees & 6 & & 6 & 8 \\
\hline $\begin{array}{l}\text { No comment/ } \\
\text { neutral }\end{array}$ & 5 & 9 & 4 & 4 \\
\hline
\end{tabular}

\section{Table 4.3 Media responses to Harper's 7 October 2008 speech}

The media analysis reported in Table 4.3 demonstrates a substantial lack of support for the national leader as well as the proposed policy implications. There was marked disagreement about the severity of the global financial crisis, with six out of the 13 articles analysed refuting Harper's argument that Canada's financial system was sound and criticising his resistance to introduce special measures to deal with the crisis. The research clearly indicated that the familiar meaning-making script aimed at convincing voters that the government anticipated the current problems back in August 2007 had failed. Of the 13 articles analysed, nine questioned Harper's proposed policy implications and expressed concerns about the government's understanding of the global financial crisis. This was significant given that Harper, a professional economist, had traditionally been able to control the domestic economic debate.

Having said that, despite Harper's incumbency, little mention (and no disagreement with the government) was made of the causes of the crisis. The coverage implied agreement with Harper's diagnosis of the causes of the crisis being exogenous. At least in part, this was testament to the strength of the 
reputation he built throughout his tenure as a competent, sensible and pragmatic economist.

A major criticism of Harper was his perceived inability to communicate empathy for the anxieties of the Canadian people or to reach out with convincing reassurance to those who reasonably continued to fear losing their jobs, losing their savings and deferring their hopes of retirement. Eight of 13 articles surveyed berated Harper for his lack of sensitivity. Harper's suggestion that stock market bargain hunters could benefit from the economic panic became a particular target. There were also some concerns that the lack of sensitivity was a portent of future inflexibility, particularly if the Conservatives were delivered a majority at the election. The fact that he delivered the speech to the Empire Club of Canada (as opposed to a group of factory workers, for example) only exacerbated the perception that Harper's response to the global financial crisis was cerebral and out of touch. The voters appeared to share the scepticism of some of the media. According to a Harris/Decima opinion poll taken one day after the speech (and eight days out from the election), only 31 per cent of decided voters supported the Conservative Party - down from a high of 41 per cent one month earlier (Heard 2008). All of this probably accounted for the fact that the title of the speech was amended from 'True north strong and free: Stephen Harper's plan for Canada' to something less self-congratulating before it was placed on the Prime Ministerial web site.

\section{October 2008: a re-elected Harper opens the new Parliament}

Opening the new Parliament, this speech was a broad-strokes outline of the government's agenda. The Throne Speech is traditionally a vague statement of priorities for the new government. It did not contain any details of the economic stimuli (the government did not release these until the budget announcement at the end of January 2009). For the most part, Harper stuck to pledges he and his Conservative Party made in the election campaign, but warned that the country could be headed back into deficit because it would be 'misguided' to inflict economic pain to avoid it. The speech was a sober one, evoking great battles of World War I and the subsequent generation that 'overcame the Depression and again confronted the devastation of war'. In all, it was a clear attempt by Harper to manage public expectations by acknowledging the severity of the situation, yet at the same time highlighting that no matter how serious the economic downturn might be, far greater challenges had been met and overcome in Canadian history. 


\begin{tabular}{|l|l|l|l|l|}
\hline & Severity & Causality & $\begin{array}{l}\text { Policy } \\
\text { implications }\end{array}$ & $\begin{array}{l}\text { Support for } \\
\text { speaker }\end{array}$ \\
\hline Agrees & 4 & & 2 & 2 \\
\hline Disagrees & & & 3 & 3 \\
\hline $\begin{array}{l}\text { No comment/ } \\
\text { neutral }\end{array}$ & 2 & 6 & 1 & 1 \\
\hline
\end{tabular}

\section{Table 4.4 Media responses to Harper's 17 October 2008 speech}

The speech enjoyed a low-key, but mixed reception in the press (Table 4.4). Of the six articles analysed, three expressed disagreement with the speaker and his policy proposals. Although most articles agreed with Harper's perception of the severity of the crisis (as conveyed in the speech), a major point of concern appeared to be the suggestion that Canada could return to deficit spending. This might have been an unintended consequence of Harper's reluctance to publicly convey the real severity of the economic crisis and manage public expectations accordingly (and consistently) during the preceding election campaign.

Interestingly, it appears that Harper's adherence to tradition in avoiding using the Throne Speech to exploit the economic crisis politically backfired on him. The New Democratic Party's leader, Jack Layton, criticised Harper's address for lacking any bold or significant action with regard to the economic crisis. He argued that this was another illustration of Harper's lack of empathy for ordinary Canadians - a criticism that was readily picked up by five out of six articles analysed. This highlights one of two things: either Harper's inability to interpret the national mood (a common criticism of his leadership) or his sound judgment in preferring to be criticised for sticking to tradition in times of crisis rather than inappropriate exploitation (and potentially, partisanship). To Harper's credit, the Throne Speech was not one that usually received significant amounts of coverage, so while the former criticism might have been common, unless especially controversial, this particular speech was never likely to be brought up against him by his critics in the future.

Given how general the speech was, how little coverage it received and how few policy announcements it contained, it was surprising that it was met with such relative disapproval. This could be attributed to the widespread feeling of disillusionment after the election. A national qualitative study conducted by Ensight Canada the day after the election found that there was widespread consensus that the election was 'a waste of time and money' and 'prevented meaningful action being taken to protect Canada's economy amidst the financial crisis' (Watt 2008:2-4). The study showed that the voters were disappointed with Harper's vision and program for the economy during the election, but chose him 'as the best of an unhappy set of choices' (Watt 2008:1-2). As such, 
this speech illustrates that the capacity of a leader's rhetoric to influence public debate is always limited by the broader context of public mood.

\section{January 2009: Finance Minister Flaherty's budget speech}

Flaherty characterised his budget as necessary to protect jobs and businesses from the ravages of the financial crisis. The financial plan devoted about half of the new spending to construction projects that Flaherty hoped would revive the economy by creating new jobs and stoking demand for lumber and other Canadian-made goods. In what was his fourth budget in three years, Flaherty offered consumers a tax break on home renovations and pledged to expand employment-insurance benefits for two years. Flaherty also stated that the Conservative Government would make available another $\$ 70$ billion in credit to businesses that were struggling to find affordable loans as a result of the global financial crisis. Although Flaherty used powerful language to introduce and conclude this lengthy speech, the urgency he hoped to convey did not really capture the media's imagination. Not unusually for a budget speech, the majority of the coverage focused on policy rather than sentiment.

\begin{tabular}{|l|l|l|l|l|}
\hline & Severity & Causality & $\begin{array}{l}\text { Policy } \\
\text { implications }\end{array}$ & $\begin{array}{l}\text { Support for } \\
\text { speaker }\end{array}$ \\
\hline Agrees & 12 & 5 & 7 & 7 \\
\hline Disagrees & 4 & 2 & 13 & 9 \\
\hline $\begin{array}{l}\text { No comment/ } \\
\text { neutral }\end{array}$ & 8 & 17 & 4 & 8 \\
\hline
\end{tabular}

\section{Table 4.5 Media response to Flaherty's 27 January 2009 speech}

The major point of concern in media reception of the speech was that the policies and measures proposed by the Harper Government were inappropriate to the national needs (Table 4.5). While the majority of the coverage expressed agreement with Flaherty about the severity of the crisis, there was a strong view that the budget's lack of a single compelling direction - 'the whole leaves the impression of miscellany' (The Globe and Mail 2009) — was evidence of it having fallen prey to political engineering. This led many to disagree with the proposed policy implications - and, therefore, with the necessity of the debt they brought with them.

Most articles, however, agreed that the government had to step up in times of crisis and did not refute the need for stimulus. This support was also reflected in a research poll, conducted in early February, which indicated that 56.6 per cent of Canadians at least somewhat supported deficit spending to stimulate the economy (Nanos 2009). The research also revealed, however, that a common sentiment was that the recession should be seen as an opportunity 'to do what 
needs to be done anyway' (Ivison 2009a) so that Canada could emerge from it 'leaner and meaner' (Corcoran 2009) than before. Instead, the overwhelming opinion was that the budget needlessly pandered to the masses at the expense of Canada's future economic prosperity.

Of the 24 articles analysed, 13 argued in some way that the budget lacked foresight and was based on wishful thinking that revenues would recover and grow more quickly than spending by the next election. Inarguably, this would have been exacerbated by the still-lingering criticisms that the Harper Government saw the economy through rose-coloured glasses and therefore did not realise the gravity of going into deficit. The research indicated that while there was a belief that the government might have been well intentioned, the overwhelming suspicion was that help for the Canadian economy would arrive too late, in the wrong place and hang around longer than expected.

These concerns did not, however, translate into strong public disapproval of Flaherty as a leader. Overall, he was seen as beholden to Harper, whose imposing leadership style and public presence were well documented. Flaherty's own merits were overtly criticised in only one article; the rest were critical of him only by the virtue of being Harper's Finance Minister. This also translated into assessments of Flaherty's performance: only those who agreed with the Harper Government more broadly tended to be complimentary of Flaherty.

Coverage of the budget three months after it was introduced was far more positive, despite the massive and growing gap between the number of Canadian job losses and the jobs target in the budget (Akin 2009). This suggested the government's attempts to convince the Canadian public that benefits of stimulus measures would take some time to filter through the economy had been successful.

\section{February 2009: bank governor Carney's 'realism'}

Carney used this address to reiterate his forecast that after a challenging first half, 'the economy will rebound at the fastest pace in decades'. This was almost twice the pace forecast by the International Monetary Fund (IMF) and most private-sector economists (Schoffield 2009). Carney confidently spoke of the Bank of Canada's economic outlook, but said that it would materialise only if the United States and other major economies took 'exceptional' measures to end the crisis in financial markets. In reply to a suggestion by John McCallum, the Liberal's finance critic, that the bank was going 'out on something of an optimistic limb', Carney replied, 'We don't do optimism. We do realism at the Bank of Canada. We don't do spin.' He added that the Bank of Canada would continue to monitor economic and financial developments carefully and 'will continue to set monetary policy consistent with achieving the two per cent inflation target over the medium term'. 


\begin{tabular}{|l|l|l|l|l|}
\hline & Severity & Causality & $\begin{array}{l}\text { Policy } \\
\text { implications }\end{array}$ & $\begin{array}{l}\text { Support for } \\
\text { speaker }\end{array}$ \\
\hline Agrees & 5 & 2 & 4 & 5 \\
\hline Disagrees & 1 & & 1 & 1 \\
\hline $\begin{array}{l}\text { No comment/ } \\
\text { neutral }\end{array}$ & & 4 & 2 & \\
\hline
\end{tabular}

Table 4.6 Media responses to bank governor Carney's 10 February 2009 speech

While Carney's positive outlook had hitherto been met with considerable scepticism, his plain assertion that the Bank of Canada did not 'do spin' appeared to resonate well. This lent his latest crisis assessment considerable legitimacy and in turn enabled greater control of the message (Table 4.6). Four of the six analysed articles emphasised in some way that the predictions of the Bank of Canada were based on economic models and data and therefore should not be dismissed as mere rhetoric or personal grandstanding (like that of political leaders). In other words, Carney could be trusted. This accounted for the broad support for the policy implications Carney recommended, as well as the agreement with his assessment of the severity of the crisis.

In addition, five out of six surveyed articles lent their support to Carney's leadership. This was in marked contrast with previous coverage, which tended to stay neutral on this issue. Portrayal of Carney as a credible leader did not change even when he adjusted his outlook two weeks later by cutting the Bank of Canada's interest rate in half to just 0.5 of a percentage point and admitting that there would be 'a sharper decline in Canadian economic activity' in the next couple of months 'and a larger-than-expected erosion of business and consumer confidence could mean the economy will not begin to bounce back until early 2010' (Bank of Canada 2009). Despite the fact that this essentially proved Carney's earlier critics right, the media attack focused on Harper's personal leadership instead, and again gave rise to suggestions that Harper and Flaherty were not prepared for the recession, did not understand what was going on and were ill equipped to deal with the economic crisis.

\section{February 2009: Flaherty attempts to rally the public}

Flaherty's piece in the opinion section of the National Post sought to reassure Canadian families and businesses that the new federal budget would help cushion the impacts of the downturn and support those hit hardest by the global financial crisis. He reasserted the Harper Government's line about the causes of the crisis (exogenous) and that of the virtues and near-invulnerability of the Canadian financial system. While acknowledging that 'there is not [a] magic bullet to return the world economy back to previous heights' and that the United States' 
recovery was essential to Canada's, he assured his readers that the Conservative Government had acted swiftly to 'keep our edge'. And, like Harper, he reiterated once again that most countries were far worse off than Canada. He went on to recapitulate the key points of the 2009 budget and ended by urging his fellow parliamentarians to 'set games aside' and put his plan to work, arguing that delay and 'obstructionism' were no longer appropriate in such difficult times.

It is quite unusual for a Canadian Finance Minister to write a column in a major national newspaper, so one could conclude that by this virtue alone the piece might have attracted some attention. Flaherty's article, however, received very few reader comments (four) and even less media coverage. There was only one short article, also in the National Post, and it focused mainly on Flaherty's point that the United States' recovery would be essential for Canada to pull itself out of the economic quagmire. In media terms, this framing attempt went down like a lead balloon (Table 4.7).

\begin{tabular}{|l|l|l|l|l|}
\hline & Severity & Causality & $\begin{array}{l}\text { Policy } \\
\text { implications }\end{array}$ & $\begin{array}{l}\text { Support for } \\
\text { speaker }\end{array}$ \\
\hline Agrees & & & & \\
\hline Disagrees & & & & 1 \\
\hline $\begin{array}{l}\text { No comment/ } \\
\text { neutral }\end{array}$ & 1 & 1 & 1 & 1 \\
\hline
\end{tabular}

\section{Table 4.7 Media responses to Flaherty's 23 February 2009 article}

A thorough search of other media outlets not included in this study (including regional newspapers in Flaherty's native Ontario) also failed to produce any findings. This lack of national interest points to a number of things. First, that Flaherty's rhetoric simply failed to kindle public interest. If Harper was frequently portrayed as dull and uncharismatic by the Canadian media (for example, Martin 2008), Flaherty seldom said anything that Harper had not already said in almost exactly the same way. There was never any disagreement or disparity between the two leaders, so for journalists there was little incentive to cover Flaherty's utterances. Second, in most countries, the Minister for Finance (Canada's equivalent of Treasurer) tends to be viewed as the expert on most macroeconomic questions. Harper's extensive background as an economist, however, and the fact that his credibility as a prime minister was built almost entirely on his reputation as a great economic tactician and manager, meant that as far as public opinion was concerned, Flaherty's views and statements were redundant. Moreover, Harper's dominance of cabinet-some commentators referred to his alleged 'controlling' and 'secretive' leadership style (Travers 2007) - left little room for Flaherty to make his own mark in the public eye, despite his central position in the Harper Government. Finally, this lack of media 
interest could indicate that Canadians were growing tired of hearing the same thing from their government since its re-election.

Indeed, the government's messaging was highly consistent throughout the period under study, enabled by a weak and fractured opposition, which had helped develop the budget in the first place. On one level, all of this might suggest that the Harper Government had some success in controlling the meaning-making script of the global financial crisis in Canada. Indeed, the United States casts a long shadow on Canada and few would disagree that any Canadian recovery was not feasible without a US recovery. On another level, however, this lack of engagement might be a marker of public despondency and apathy regarding the government and its limited ability to do anything about the global financial crisis at home. The lukewarm opinion polls provide some support for such an interpretation (Strategic Counsel, CTV and Globe and Mail 2009).

\section{March 2009: Harper's continued optimism}

Although this particular address appeared to be an attempt by Harper to promote his government's action to reduce red tape to ensure the efficient delivery of stimulus measures, media coverage of the speech largely ignored the intended message. Instead, it focused squarely on Harper's optimistic outlook for the Canadian economy. 'Typically a politician who likes to under-promise and over-deliver' (Laghi 2009), Harper asserted that Canada would be the first major country to come out of the recession, that Canada had been hurt by it much less than other countries and that Canada's banking system was the soundest in the world. He reminded the audience about some of the budget measures designed to stimulate the economy, such as the home renovation tax credit. In addition, Harper announced his frustration 'with the opposition since the election' and encouraged his audience to tell the Liberal Party to 'stop the political games'. The overall tone was one of boosting morale, with Harper going as far as saying that 'if ever there was a time to put away that legendary Canadian modesty, it is now'.

It is important to note that Harper chose to deliver this speech in Brampton, Ontario. Ontario is sometimes called 'car country' because its economy relies so greatly on automobile manufacturing. General Motors, Ford and Chrysler had been producing more cars and light trucks in Ontario than Michigan - due in part to the generous health care available in Ontario (Fry 2009:37). With all three companies suffering deep financial setbacks, Ontario's manufacturing sector had been devastated almost to the same extent as Michigan's (Hamilton Chamber of Commerce 2009). Of all Canadian provinces, Ontario had been the most severely affected by the global financial crisis. The largest employers in Brampton were Chrysler and General Motors and the city had experienced a dramatic increase in unemployment; figures from Statistics Canada show that Brampton's unemployment in March was 10.9 per cent, 2 percentage points higher than the 
rest of Ontario (8.9 per cent) and higher still than the national rate (8.3 per cent) (Statistics Canada 2009a).

Harper's choice of venue and upbeat rhetoric suggested a deliberate attempt to reassure the most-affected Canadians of his government's competency. In addition, his attack on the opposition presented an attempt to exploit the crisis to his party's advantage. This alleged inability to curb his partisan instincts was perceived by some commentators as antagonistic and irrational (given that Harper did not enjoy a majority government and that, without the opposition's cooperation, the government's vaunted economic plan would not have been produced with so few adjustments).

\begin{tabular}{|l|l|l|l|l|}
\hline & Severity & Causality & $\begin{array}{l}\text { Policy } \\
\text { implications }\end{array}$ & $\begin{array}{l}\text { Support for } \\
\text { speaker }\end{array}$ \\
\hline Agrees & 1 & & 2 & 1 \\
\hline Disagrees & 5 & & 2 & 4 \\
\hline $\begin{array}{l}\text { No comment/ } \\
\text { neutral }\end{array}$ & 2 & 8 & 4 & 3 \\
\hline
\end{tabular}

\section{Table 4.8 Media responses to Harper's 10 March 2009 speech}

The media analysis shows a preponderance of disagreement with Harper about the severity of the crisis (Table 4.8). Of eight articles analysed, five were critical of Harper's 'rose-tinted' (Ivison 2009b) view of the Canadian economy. Seven gave a platform to the Liberal leader, Michael Ignatieff's, condemnation of Harper as being 'on a Conservative planet, off in outer space'. A number of articles implied that Harper's boisterous outlook rang hollow with the Canadian public. One captured the mood by observing 'yes, Canada is in good shape relative to everyone else, but that doesn't mean we're in good shape relative to our own expectations and our own standards' (Cowan 2009). A closely related criticism was that Harper's 'boasting' was tactless and completely out of touch with the reality of the difficulties many Canadians faced as a result of the crisis (Radwanski 2009).

With Harper's assessment of the severity of the crisis clearly contested (in contrast with the question of causation, which was widely ignored, reflecting a broad consensus about this being overwhelmingly exogenous), there were some concerns about the policy direction the government was taking to deal with it. Overall, however, the coverage of policy implications was mostly neutral, probably enabled by the opposition's focus on criticising Harper's lack of sensitivity rather than his policy trajectory (quite probably because the opposition approved the economic plan with very few adjustments and little debate). Clearly, at this point, crisis politics and crisis policy had become divorced in the rhetoric of all the major parties. It is worth mentioning that reader 
comments (not included in the quantitative assessment) did express concerns about Harper's policy decisions, particularly the proposed tax reform. When coupled with the low-level coverage this speech received, this suggested that the extent of public disapproval of Harper could have been greater than these findings implied. Indeed, a Harris Decima election tracing opinion poll shows that public approval for the Conservative Party fell to 29 per cent between 8 March and 29 March - down from 33 per cent in late February and early March (Harris Decima 2009).

\section{April 2009: the bank governor sees light at the end of the tunnel}

With the US and global economies plunging deeper and deeper into recession, Carney used his address in Yellowknife to reassure Canadians that they could be confident that unprecedented policy measures would - eventually - restore growth. Using the most powerful language to date (far stronger than any of Harper's or Flaherty's public utterances), Carney acknowledged that these were 'very challenging times' for an economy 'in the most severe financial meltdown since the Great Depression'. He also remarked that the current crisis was more challenging than previous downturns because it represented more than a cyclical shock. He said that Canadians were understandably more concerned about their economic future than they had been in decades, but he added that 'there is a plan to restore confidence and growth, we are implementing it, and it will work'.

\begin{tabular}{|l|l|l|l|l|}
\hline & Severity & Causality & $\begin{array}{l}\text { Policy } \\
\text { implications }\end{array}$ & $\begin{array}{l}\text { Support for } \\
\text { speaker }\end{array}$ \\
\hline Agrees & 4 & 2 & 4 & 4 \\
\hline Disagrees & & & 1 & \\
\hline $\begin{array}{l}\text { No comment/ } \\
\text { neutral }\end{array}$ & 1 & 3 & 1 & 2 \\
\hline
\end{tabular}

\section{Table 4.9 Media responses to Carney's 1 April 2009 speech}

This speech, although optimistic in parts, was a marked departure from Carney's usually positive outlook. It was met with considerable agitation by the media. None of the media commentators questioned his assessment of the severity of the crisis, but most tended to amplify it by declaring the central bank's hitherto bullish outlook officially buried. Carney's personal leadership also went unquestioned, but his pessimism gave rise to criticisms of Flaherty and Harper's refusal to increase the size of the government's stimulus program. Three out of the five articles called for the increase, despite the fact that in the same speech Carney warned about the dangers of overshooting the target with stimuli.

The criticisms of Harper were particularly interesting since, as one of the articles noted, he had indicated in a series of recent interviews with foreign media that 
policymakers must do 'everything necessary' to pull the global economy out of the crisis - a sentiment clearly at odds with Carney's reservations (Vieira 2009). While a disparity of views between the Prime Minister and the Bank of Canada Governor would theoretically make for interesting coverage (particularly given the vastly different reputations the two enjoyed), in this instance, it failed to capture public imagination. Nor did it seem to get the attention of the opposition.

\section{Framing the financial crisis in Canada: analysis and conclusions}

Because the real extent of the effects of the global financial crisis on the Canadian economy was not revealed until late in 2008 , the government was able to frame the crisis in optimistic terms for most of the year. In this, they were greatly enabled by their incumbency and Harper's reputation as a competent economic manager. His credentials as an 'economist by training' and his government's perceived competence at managing the national economy had been readily circulated by the Canadian media for a long time. These were his major electoral strengths before the economic downturn began in earnest. In contrast, during 2008, the major opposition party, the Liberal Party (which had held government for 12 years before Harper's victory in 2006), was led by the highly unpopular Stephane Dion. A former political science academic, Dion was widely perceived as 'a thinker rather than a doer... a pie-in-the-sky intellectual' who was frequently unable to explain basic economic realities (McLean 2008:12). Harper recognised this weakness and frequently sought to exploit it. In fact, it was commonly accepted that Harper's surprising decision to call an early election in September was motivated largely by his recognition of the public perception that the Liberal Party (and especially Dion) was ill equipped to lead Canada through perilous times. Michael Ignatieff, another intellectual, replaced Dion in December. Dion's disastrous period of leadership, however, had an enduring impact on the credibility of the party and continued to compromise the public perception of the party's economic management credentials throughout 2009.

As the findings of this study indicate, however, Harper overestimated his ability to shape public opinion and exploit the crisis to his advantage. By the time the election campaign started in September and the Wall Street collapse began in earnest, Canadians began to question his persistently rosy outlook on the state of the economy. Although Harper's previous policies were not blamed for causing the crisis, significant portions of the commentariat as well as most ordinary Canadians did not believe that problems south of the border would not eventually affect the Canadian economy. Harper's unwillingness to concede the severity of the crisis created an impression that he was putting his political interests ahead of his economic knowledge. This eventually raised concerns about the policy direction the government was taking to deal with the crisis. 
The government's credibility could in theory have been assisted by the fact that Flaherty's messaging was consistent with Harper's throughout the crisis. Harper's dominant leadership style, however, and his tendency to speak for the government on all matters regarding the economy throughout the Conservatives' tenure had long ago compromised the capacity of the Minister for Finance to shape public debate. Consequently, Flaherty's pronouncements were ignored at best and, at worst, were seen as politically motivated and thus were cynically received.

It might have been helpful for Harper to emphasise the similarities between his outlook and that of Bank of Canada Governor, Mark Carney, since the latter's apolitical office meant that the public did not question his agenda. Given Harper's vested interest in avoiding implicating his government in the causes of the domestic manifestations of the global financial crisis, however, it is not surprising that he should want to distance himself from the Bank of Canada's past (and for that matter, future) fiscal policy decisions. By the same token, it is reasonable to assume that if Harper were to publicly align himself with Carney, the credibility of the Governor of the Bank of Canada would be compromised in more ways than one.

Moreover (and somewhat ironically), Harper's unwillingness to resort to explicit crisis rhetoric fed into pre-existing perceptions of him as a cold, uncaring leader who lacked sympathy for the plight of everyday Canadians. This was exacerbated as the effects of the global financial crisis on the Canadian economy became increasingly obvious. Instead of convincing voters that his government anticipated the problems long before they became apparent, Harper's continuous resistance to introducing special measures to deal with the crisis led Canadians to question whether the government realised the gravity of the global financial crisis - and consequently, whether it was equipped to deal with the crisis appropriately and effectively.

By clinging to a positive outlook that was increasingly portrayed as overoptimistic, Harper painted himself into a corner. When he and his government were eventually forced to admit that the country was in recession, this was widely perceived as backtracking. It seemed to confirm growing fears that perhaps Harper was not the amazing economic manager Canadians had come to believe he was. It was no surprise then that the Canadian public received the 2009 budget - which projected a huge deficit — with considerable suspicion.

It is worth questioning why this erosion of credibility under the weight of the escalating economic problems failed to pose any significant political threat to the Harper Government. One of the answers lies with the weak and politically divided opposition parties, which failed to challenge the Conservatives in any meaningful way. An international observer might intercede here and note that surely the December 2008 parliamentary crisis constituted one such memorable 
challenge. If anything, however, the parliamentary crisis served to affirm the position of the Harper Government. National polls conducted during and after the impasse suggested that although Canadians were beginning to have more doubts about the Harper Government's economic competence, they were even more cynical about the opposition parties' ability to form a fungible coalition (reservations that were amplified by their very colourful public disagreements during the election period). To some extent, Canadians even seemed to blame the opposition parties for the crisis (Reuters 2008). As a matter of fact, the proposed alternative coalition government fell apart during its very first test - the 2009 budget - thus ending the parliamentary crisis.

One of the main reasons why the opposition parties failed to present a threat to the government was their unwillingness to challenge it on the very issue of economic management until well into 2009. The main opposition parties consistently echoed Harper's optimistic outlook; they all initially downplayed the economic crisis. Even during the election campaign, as the markets went into free fall, average Canadians watched their investments begin to evaporate and the economic crisis was obviously spiralling out of Harper's control, Dion and his opposition counterparts, Jack Layton (of NDP) and Gilles Duceppe (of Bloc Quebecois), did not question his mantra of 'the fundamentals of the Canadian banking system remain strong' and 'Canada is well placed to weather the economic storm'. The budget presented another obvious opportunity for the opposition to effectively challenge the government's credibility in addressing the global financial crisis. Indeed, it committed Canada to a $\$ 38$ billion deficit just two months after Harper asserted that Canada was doing fine and would even produce a surplus in the next financial year. The opposition parties, however, spent so much time attacking one another's stances on the budget that the infighting attracted almost as much media coverage as the budget itself.

All of this considered, it is important to conclude with a reflection on what is perhaps the most interesting finding of this study: the notable lack of media interest in the manner in which the Canadian Government was handling the domestic manifestations of the global financial crisis. The reasons for this lack of interest are very difficult to pin down, but two speculations can be offered. First, Canada is saturated with US media outlets so it is possible that Canadians' view of the crisis was shaped more by the bombardment of alarmist crisis rhetoric and imagery beamed into their homes from south of the border than by the public pronouncements of their own leaders. Canadians might therefore have viewed the economic downturn as far too colossal for their government to halt at home, and consequently might have held low expectations of their leaders' capacity to affect change. In this case, it would have been in the interests of Harper and Flaherty to stick with their usual bland rhetoric so as not to attract further media attention. 
It is also possible that the lack of media interest in the government's efforts to frame the crisis was a symptom of a general sense of disillusionment, cynicism and distrust of the government and the opposition among Canadians - that is, a sign of general disengagement from the political process. It might have been the case that Canadians were deeply sceptical of their government's handling of the crisis, but sensed that things could be much worse if the squabbling opposition parties held the reins. A telltale indicator of this alternative interpretation was that voter turnout at the October 2008 election was the lowest in Canadian history (CBC News 2008). Regardless of the reasons, this notable absence of media interest and serious pushback helped keep the Conservative Government firmly in the saddle: it was exercising crisis leadership by default.

\section{References}

Akin, D. 2009, 'Interview: Flaherty says he's sticking with budget', National Post, 11 April.

Bank of Canada 2009, Bank of Canada lowers overnight rate by 0.5 percentage point to 0.5 per cent, Press release, 3 March, viewed 1 July 2009, <http://www.bankofcanada.ca/en/fixed-dates/2009/rate_030309.html>

Callan, E. 2008, 'Tory adaptation of bank PR even surprises banks', Financial Post, 15 October.

Canadian Newspaper Association 2008, Daily Newspaper Circulation Data: 2008, Canadian Newspaper Association, viewed 1 July 2009, $<$ http://www.cna-acj.ca/en/aboutnewspapers/circulation>

CBC News 2008, 'Voter turnout drops to record low', CBC News, 15 October, viewed 1 July 2009, $<$ http://www.cbc.ca/news/canadavotes/story/2008/10/15/voter-turnout.html>

Clark, A. 2008, 'Buffett says: act or face 'economic Pearl Harbor', The Guardian, 25 September, viewed 20 May, <http://www.guardian.co.uk/business/2008/sep/25/banking.wallstreetl>

Corcoran, T. 2009, 'Flaherty digs himself a deep, dark hole', National Post, 27 January.

Cowan, J. 2009, 'Harper boasts of Canada's recession plan', Financial Post, 10 March.

Economist 2008, 'Editorial: please have the decency to panic: economic fears ambush Harper's hopes of a majority', The Economist, 9 October.

EKOS and Associates Poll 2008, 'Outlook on the current situation: preferred solution for current political impasse', 4 December, EKOS and Associates Poll, viewed 1 July 2009, 
<http://www.ekoselection.com/wp-content/uploads/

1069-cbc-results-dec-4-final-with-analysisl.pdf>

Financial Consumer Agency of Canada 2008, Moving forward with financial literacy: synthesis report on reaching higher, Canadian Conference on Financial Literacy, September.

Fry, E. H. 2009, 'Canada's economic relationship with the United States', Policy Options, April.

Globe and Mail 2008, 'Editorial: Harper stays true to form', The Globe and Mail, 8 October.

Globe and Mail 2009, 'A missed chance to build toward Canada's future', The Globe and Mail, 28 January.

Hamilton Chamber of Commerce 2009, Manufacturing Job Losses, March, Hamilton Chamber of Commerce.

Harris Decima 2009, Liberals maintain edge nationally, National vote intention table, Press release, 21 April, Harris Decima, viewed 1 July 2009, $<$ http://www.harrisdecima.com/en/downloads/pdf/news_releases/042309E.pdf>

Heard, A. 2008, Canadian election opinion polls, Political Science Department, Simon Fraser University, viewed 1 July 2009, <http://www.sfu.ca/ aheard/elections/polls.html>

Hopkins, A. 2009, 'Canada's Banks seen profiting from stronger markets', The Globe and Mail, 25 May, viewed 20 June, $<$ http://www.globeinvestor.com/servlet/story/ROC.20090525.2009-0525T135520Z_01_TRE54O2L2_RTROPTT_0_CBUSINESS-US-BANKS/GIStory>

Ivison, J. 2009a, 'A budget for the wishful thinker in everyone', National Post, 27 January.

Ivison, J. 2009b, 'Don't worry, be Harper', National Post, 3 April.

Jones, K. 2009, 'Canada: furore over soaring federal budget deficit', The Globe and Mail, 29 May.

Laghi, B. 2009, 'Why Stephen Harper is suddenly an optimist', The Globe and Mail, 10 April, viewed 10 July 2009, <http://www.theglobeandmail.com/news/politics/article975962.ece\#article>

McLean, J. 2008, 'The messenger is the message', Options Politiques, November.

Martin, L. 2008, 'Stephen Harper: the tactics, the leadership (Part 1)', The Globe and Mail, 15 September, viewed 10 July 2009, $<$ http://www.theglobeandmail.com/servlet/story/ RTGAM.20080912.wcomartin15/BNStory/politics/home> 
Nanos, N. 2009, 'Nanos research poll', Policy Options, February.

Radwanski, A. 2009, 'He just can't help himself', The Globe and Mail, 10 March.

Reuters 2008, 'Harper has crushing poll lead on crisis', Reuters, 5 December, viewed 1 July 2009, <http://ca.reuters.com/article/topNews/idCATRE4B42X520081205/>

Schoffield, H. 2009, 'Recovery hinges on U.S. stimulus: Carney', The Globe and Mail, 10 February.

Statistics Canada 2008, Imports, Exports and Trade Balance of Goods on a Balance-of-Payments Basis, by Country or Country Grouping, Statistics Canada, viewed 1 July 2009, <http://www40.statcan.gc.ca/101/cst01/gblec02a-eng.htm>

Statistics Canada 2009a, Labour Force Survey, 8 May, Statistics Canada, viewed 1 July 2009, $<$ http://www.statcan.gc.ca/subjects-sujets/labour-travail/lfs-epa/lfs-epa-eng.htm>

Statistics Canada 2009b, Imports, Exports and Trade Balance of Goods on a Balance-of-Payments Basis, by Country or Country Grouping, 10 June, Statistics Canada, viewed 1 July 2009, <http://www40.statcan.gc.ca/101/cst01/gblec02a-eng.htm>

Strategic Counsel, CTV and Globe and Mail 2008a, 'Vote intention poll', The Strategic Counsel, 12 May, viewed 1 July 2009, <http://www.thestrategiccounsel.com/our_news/polls/ 2008-05-12\%20GMCTV\%20--\%20FINAL2.pdf>

Strategic Counsel, CTV and Globe and Mail 2008b, 'Vote intention poll', The Strategic Counsel, 10 June, viewed 1 July 2009, $<$ http://www.thestrategiccounsel.com/our_news/polls/ 2008-06-10\%20GMCTV\%20--\%20final.pdf>

Strategic Counsel, CTV and Globe and Mail 2009, 'Vote intention poll', The Strategic Counsel, 9 March, viewed 1 July 2009, $<$ http://www.thestrategiccounsel.com/our_news/polls/ 2009-03-09\%20-\%20Vote\%20Intention.pdf>

Stein, S. 2008, 'Greenspan: this is worst economy I've ever seen', The Huffington Post, 14 September, viewed 20 May, <http://www.huffingtonpost.com/2008/09/14/ greenspan-this-is-the-wor_n_126274.html>

Travers, J. 2007, 'Harper's leadership style mimics Chretien's, to a point', The Record, 27 November, viewed 1 July 2009, $<$ http://news.therecord.com/article/274938>

Vieira, P. 2009, 'Carney warns of too much stimulus', Financial Post, 2 April. 
Watt, J. 2008, 'The morning after: now for the hard part', Options Politique, November. 